\title{
Impact of Macroeconomic Variables on Growth of Assets in Islamic Banks: A Case of Pakistan
}

\author{
ZAHOOR HUSSAIN JAVED \\ Assistant Professor, Department of Economics, \\ Government College University, Faisalabad Pakistan. \\ Email: javedmarth@gcuf.edu.pk \\ MAHMOOD UL HASAN \\ Assistant Professor, Department of Economics, University of Sargodha. \\ IQRA AROOG \\ Scholars, Bahuddin Zakeriya University, Multan. \\ Email: iqraaroog97@gmail.com
}

\begin{abstract}
The foremost intention of this study is to investigate the influence of macroeconomic variables on the growth of assets in Islamic banks of Pakistan for 11 years from 2008-2018. Descriptive statistics, correlation matrix, and ordinary least square technique are used for data analysis. Thus, the findings indicate that the provision of domestic credit (\% GDP) has positive and a significant influence on the growth of assets in Islamic banks in Pakistan. The consumer price index has a negative influence on the growth of assets in Pakistan because as the consumer's price index has been risen up, consumers reduce their expenditures on goods and services, thus gathering assets in Islamic banks will be reduced. Thus, the consumer's price index has negative effect on the growth of assets in Islamic banks. The outcomes of this research are consistent with the previous studies and shows same results.
\end{abstract}

Keywords: Macroeconomics Variables, Growth of Assets in Islamic Banks, Domestic Credit, Consumer Price Index, Pakistan.

\section{Introduction}

The speed of interest in Islamic banks is growing very rapidly in the flow of assets in the industrial sector. The need for non-conventional financing has been increased for sustainable development goals; nevertheless, the interest in this study has increased due to the presence of a large portion of Islamic banks in oil-importing and the unpredictability in oil prices. Henceforth, the uncertainty of oil prices, increasing size of assets and absence of political stability in Pakistan create inspiration to search for the rudiments of Islamic banking development.

Hereafter, the snapshots of the specific formalized fact of Islamic banking may be discussed such as. The Islamic sharia is main principals of Islamic banking. The embargo of riba (interest) is the basic difference between conventional and Islamic banking. Tamimi, (2010) emphasized riba is the payments that must be taken by the lender from borrower on simple or compound interest rate after a specific period, simply it can be said "return of money on the money". Thus, Islam stops these activities like gharar, haram, and maysir which are venturing, gambling and speculation in the business. Nevertheless, production or trade-in pork or alcohol is considered illegitimate in Islam. Islam imposes Zakat for distribution of wealth to the penurious people and this one is the most important pillars of Islam for bringing stabilization of the 
economy. The agreement has occurred between two or more than two parties; wherein partner delivers financial facilities for the project and others run the business, while financer offers all the required assets, wealth and capital into the business.

The sharing of profit or loss retained from the business would be distributed among them on a specific ratio, which was settled between them. However, in the Mudrabaha covenant, the banks purchase an asset from the third party and later resell this commodity to the party on a specific mark-up for a definite period. Moreover, in Ijara contract the parties sell their goods for a specific period on specific rent and this rental payment was paid by the buyer. Now a day Sukuk is the foremost imperative financing tool in Islamic banks which are similar to some-extent to bonds in conventional banks because the interest rate is the main determinant of bonds in conventional banks, while Sukuk issuance is backed mostly with an asset.

\section{Islamic Banking and Economic Growth}

Freshly, much and more investigations have been completed on Islamic finance, Islamic banking, and economic growth. The study of Imran and Kpodar (2016) reveals that an Islamic bank is non-negatively related to the growth of assets subsequently monitoring other elements of growth. Lone and Ahmad (2017) suggested that Islamic banks are in-between organizations that offered healthier perceptions about the financial system of Islamic institutions to additional develop the industry of Islamic banking and help society better. Lone and Ahmad (2017) used the SERVQUAL model to detect customer satisfaction in Islamic banking windows and full-fledged Islamic bank and they investigated customer's perceived better image regarding Islamic banking. In the investigation of Ramlan and Adnan, (2016), Lone and Rehman (2017 establish that Islamic banks are more useful than conventional banks. Chowdhury et al. (2016) used a dynamic GMM trend and he found that macroeconomic variables like money supply, inflation, equity financing, and operating efficiency are the significantly improved performance of the Ilamic bank. The comprehensive studies of Naceur et al. (2015) and Rasid et al. (2016) give a picture of Islamic banks' performance very clearly. Abedifar et al. (2015), Gheeraert and Weill (2015), Weill, Bougatef (2015), King and Levine (1993) and Gheeraert (2015) suggest the performance of Islamic banking more and much better than conventional banks because they provide better satisfaction than a conventional bank.

So it may be said there is a robust association among the growth of the economy and the Islamic banking sector (Rajan, 1989). The economy was undermined due to the destabilization of financial institutions, while the Islamic financial institutions are going to keep their stability and sustainability (Zied, 2013). Thus, Islamic financial institutions are budding speedily in Pakistan and the rest of the world. Islamic Banking attained its twofold digit growth in Pakistan and the assets segment of the sector reaches $11.70 \%$ of the total banking industry's assets (FS Review, 2016). The foremost area of this research is to detect the effect of macroeconomic variables on sustainable Islamic banking growth. The distinctiveness of this is based on a standard growth model, others Islamic bank and macroeconomic variables like the growth rate of assets in an Islamic bank, provision of domestic credit by financial sector (\% GDP) in Pakistan and consumers prices respectively to fill the research gap in determining Islamic banking growth rate of assets. To the best of my information, no experimental work has been done on this research topic.

This paper will analyze the impact of macroeconomic variables like domestic credit provided by the financial sector (\% GDP) and consumer price on the sustainable growth of assets in the four most prominent Islamic banks in Pakistan. The following hypotheses are constructed from the above literature.

H1: Domestic credit (\% GDP) put positive effect on the growing of Islamic assets in banks.

H0: Domestic credit (\% GDP) put a negative impact on the growing of Islamic assets in banks.

$\mathrm{H} 2$ : Consumer price Index put a negative impact on the growing of Islamic assets in banks.

H0: Consumer price put a positive impact on consumer prices on the growing of Islamic assets in banks. 


\section{Research Methodology}

The foremost determination of this research is to observe the influence of macroeconomic variables on the justifiable growth of assets in the Islamic bank. The study includes the four prominent Islamic banks like Bank Islami Ltd, Albaraka bank Ltd, Meezan bank Ltd and Dubai Islamic bank Ltd respectively. Data was collected for all Data for analysis for getting objectives have been taken from annual financial reports of these banks for analysis from 2008-2018, while data of consumer price index and domestic credit by financial sector (\% GDP) have been taken from World development indicator. Furthermore, dummy variable Sharia is also used in this analysis, which shows the impact of sharia principal on the growth of assets.

The foundation of this study has been started by estimating the standard growth model which is based on the principal work of Solow production function.

The Solow production function may be described as under:

$\mathrm{Y}=\mathrm{F}(\mathrm{K}, \mathrm{L})$

Where $\mathrm{Y}$ is output, $\mathrm{K}$ is capital input, $\mathrm{L}$ is labor input, $\mathrm{A}$ is the level of technology and efficiency of work, and effective labor is AL.

The framework of the above model in the form of regression may be written as:

$\operatorname{SIBG}=\alpha+\beta_{1} \mathrm{DC}+\beta_{2} \mathrm{CP}+\beta_{3} \mathrm{SHRr}+\mu$

$\mathrm{SIBG}=$ Sustainable growth of assets of Islamic bank in Pakistan

$\mathrm{DC}=$ Domestic credit $(\%$ GDP $)$ in Pakistan

$\mathrm{CP}=$ Consumer price index

SHR $=$ Sharia is the dummy variable for Sharis.

$\mu=$ Error term

Consumer price: Macroeconomic stability provides a firm footing for a financial system in Pakistan. Thus consumer price is one of the most important variables in macroeconomic. Islamic banking is more of risk sharing, if prices are stable in Pakistan, therefore lower risk in investment leads to higher existence of financial accomplishments. It is argued that price stability increases real output growth which increases assets of Islamic banks.

Provision of domestic credit by financial sector (\% GDP) in Pakistan: As Islamic sharing activities increase, the ratio of domestic credit provided by the financial sector (\% GDP) in Pakistan also increases consequently growth rate of assets in Islamic financial institutions will be increased.

The values of mean, minimum, maximum and standard deviation are represented in Table 1.

Table No1: Descriptive Analysis.

\begin{tabular}{|c|c|c|c|c|c|}
\hline Variables & Minimum & Maximum & Mean & Median & $\begin{array}{c}\text { Standard } \\
\text { Devaitions }\end{array}$ \\
\hline SIBG & 12.23 & 14.14 & 13.28 & 13.33 & 0.67 \\
\hline DC & 0.92 & 3.00 & 2.027 & 2.04 & 0.64 \\
\hline CP & 3.75 & 4.06 & 3.89 & 3.88 & 0.08 \\
\hline
\end{tabular}

The average of the variable over the period of the analysis is measured by mean. Similarly, the diversification from the average value is represented by the standard deviation. While the maximum shows the highest value and minimum show the lowest value of the variables in the sample. The mean values of 
all variables rest between 3.89 to 13.28 . The minimum and maximum values of growth of assets in Islamic banks are 12.23 and 14.14 respectively.

3.89 is the mean value of a consumer price index, while 0.08 is the value of standard deviation for a consumer price. The maximum and minimum value of domestic credit percentage of GDP is 0.92 and 3.0 are respectively. The value of the standard deviation $0.67,0.64$ and.08 respectively indicates that this consumer price has fewer volatilities than as compared to other variables considered in the study.

\section{Correlation Matrix}

Table 2 is reported findings of correlations between all used variables. The test of correlation detects there is a correlation between -0.39 to 0.75 among all independent variables, which shows that there is not a problem of multicollinearity, nevertheless these results are verified by the test of LM. The LM test also verifies that there is no multicollinearity problem in this specific model.

Table 2: Correlation Matrix

\begin{tabular}{|c|c|c|}
\hline SIBG & DC & CP \\
\hline 1.00 & -0.86 & 0.75 \\
\hline-0.86 & 1.00 & -0.39 \\
\hline 0.75 & -0.39 & 1.00 \\
\hline
\end{tabular}

The Ordinary Least Square technique is appropriate to measure the effect of macroeconomic variables on the sustainable growth of assets in Bank Islami Ltd, Meezan bank Ltd, Albaraka bank Ltd and Dubai Islamic bank Ltd respectively.

\begin{tabular}{|c|c|c|c|c|}
\hline \multicolumn{7}{|c|}{ Table 3: Regression Results } \\
\hline Variables & Coefficient & Std.error & t-Stat & Prob \\
\hline CD & -0.45 & 0.12 & -3.59 & 0.008 \\
\hline CP & 2.40 & 0.67 & 3.56 & 0.009 \\
\hline SHR & 0.67 & 0.15 & 4.24 & 0.003 \\
\hline
\end{tabular}

The findings of ordinary least squares regression are depicted in Table 3. The value of F- statistics (59.89) shows that there is a significant association between dependent and independent variables. The value of Rsquared is 0.96 , which indicates that there is 96 percent variation takes place between dependent and independent variables. It means that domestic credit provided by the financial sector (\% GDP) in Pakistan and consumer price (CP) collectively bring 96 percent changes in the growth of Islamic banks' assets. Moreover, SHR also influences the growth of assets in Islamic banks. The results of this study are consistent with the findings of Imran and Kpodar (2016) who conclude that macroeconomic variables improve the performance of Islamic banks.

\section{Conclusion}

The findings of this research point out that domestic credit (\%GDP) has positive and a significant impact on the growing of Islamic assets in Pakistani in Islamic banks. It means that domestic credit plays a very fundamental role in the growing of assets in Islamic banks. The consumer price index has a negative impact on the growth rate of assets in Pakistan because as well as the consumer's price index has been risen up, consumers reduce their expenditures on goods and services, thus gathering assets in Islamic banks will be reduced. Thus, the growth rate of assets in Islamic banks is negatively affected by the consumer's price index. The results of this study are consistent with the foregoing study of Imran and Kpodar (2016) and Chowdhury et al. (2016) who conclude that macroeconomic variables are significantly related to Islamic 
bank performance. Future studies can be done for comparing the role of conventional banks and Islamic banks in economic growth.

\section{References}

Abedifar, P., Ebrahim, S. M., Molyneux, P., \& Tarazi, A. (2015). Islamic banking and finance: recent empirical literature and directions for future research. Journal of Economic Surveys, 29(4), 637-670.

Al-Tamimi, H., \& Hussein, A. (2010). Factors influencing performance of the UAE Islamic and conventional national banks. Global Journal of Business Research, 4(2), 1-9.

Bougatef, K. (2015). The impact of corruption on the soundness of Islamic banks. Borsa Istanbul Review, 15(4), 283-295.

Chowdhury, M. A. F., Haque, M. M., \& Masih, M. (2017). Re-examining the determinants of Islamic bank performance: new evidence from dynamic GMM, quantile regression, and wavelet coherence approaches. Emerging Markets Finance and Trade, 53(7), 1519-1534.

Ftiti, Z., Nafti, O., \& Sreiri, S. (2013). The efficiency of Islamic banks during the subprime crisis: Evidence of GCC countries. Journal of Applied Business Research (JABR), 29(1), 285-304.

Gheeraert, L. (2014). Does Islamic finance spur banking sector development?. Journal of Economic Behavior \& Organization, 103, S4-S20.

Gheeraert, L., \& Weill, L. (2015). Does Islamic banking development favor macroeconomic efficiency? Evidence on the Islamic finance-growth nexus. Economic modelling, 47, 32-39.

Hesse, H. (2009). Export diversification and economic growth. Breaking into new markets: emerging lessons for export diversification, 55-80.

Imam, P., \& Kpodar, K. (2013). Islamic banking: how has it expanded?. Emerging Markets Finance and Trade, 49(6), 112-137.

Imam, P., \& Kpodar, K. (2016). Islamic banking: Good for growth?. Economic Modelling, 59, $387-401$.

King, R. G., \& Levine, R. (1993). Finance and growth: Schumpeter might be right. The quarterly journal of economics, 108(3), 717-737.

Lone, F. A., \& Ahmad, S. (2017). Islamic finance: more expectations and less disappointment. Investment Management and Financial Innovations, 14(1), 134-141.

Lone, F. A., \& Rehman, A. U. (2017). Customer satisfaction in full-fledged Islamic banks and Islamic banking windows: A comparative study. Journal of Internet Banking and Commerce, 22(S7).

Naceur, S. B., Barajas, A., \& Massara, A. (2017). Can Islamic banking increase financial inclusion? In Handbook of Empirical Research on Islam and Economic Life. Edward Elgar Publishing.

Rajan, R. G., \& Zingales, L. (1998). Which capitalism? Lessons form the east Asian crisis. Journal of Applied Corporate Finance, 11(3), 40-48.

Ramlan, H., \& Adnan, M. S. (2016). The profitability of Islamic and conventional bank: Case study in Malaysia. Procedia Economics and Finance, 35, 359-367.

Rashid, A., \& Jabeen, S. (2016). Analyzing performance determinants: Conventional versus Islamic banks in Pakistan. Borsa Istanbul Review, 16(2), 92-107. 